\title{
ST
}

Science \& Technology

PAPER - OPEN ACCESS

\section{Pendekatan Chemo-Entrepreneurship Pada Minat Kewirausahaan Siswa SMA N 1 Bukit Perubahan Materi}

\author{
Author : Sri Ismulyati dkk., \\ DOI $\quad: 10.32734 /$ st.v2i1.347 \\ Electronic ISSN $\quad:$ 2654-7082 \\ Print ISSN : $2654-7074$
}

Volume 2 Issue 1 - 2018 TALENTA Conference Series: Science \& Technology (ST)

This work is licensed under a Creative Commons Attribution-NoDerivatives 4.0 International License.

Published under licence by TALENTA Publisher, Universitas Sumatera Utara

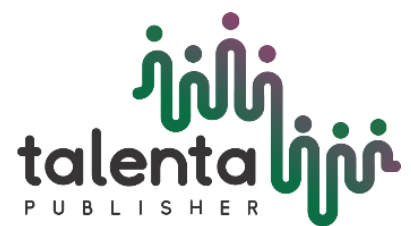




\title{
inili

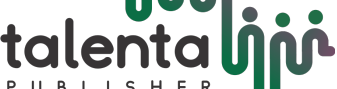 TALENTA Conference Series \\ Available online at https://talentaconfseries.usu.ac.id \\ Pendekatan Chemo-Entrepreneurship Pada Minat Kewirausahaan Siswa SMA N 1 Bukit Perubahan Materi
}

\author{
Sri Ismulyati ${ }^{\text {a* }}$ dan Yudi Ikhwani ${ }^{\mathrm{b}}$ \\ ${ }^{a}$ Program Studi Pendidikan Kiamia, Universitas Serambi Mekkah, Banda Aceh \\ ${ }^{b}$ Pendidikan Kimia Fakultas Keguruan dan Ilmu Pendidikan Universitas Serambi Mekkah, Banda Aceh \\ sriismul@gmail.com
}

\begin{abstract}
Abstrak
Rendahnya mutu lulusan berakibat pada rendahnya kemampuan kompetitif dan komperatif lulusan. Namun pada kenyataannya banyak siswa SMA yang tidak dapat melanjutkan ke jenjang pendidikan yang lebih tinggi sehingga berpotensi untuk menjadi pengangguran. Dalam penelitian ini untuk meningkatkan minat kewirausahaan dan respon siswa proses pembelajaran kimia perlu adanya suatu inovasi dan pembaharuan dalam suatu pendekatan Chemo-Entrepreneurship (CEP). Kabupaten Bener Meriah merupakan bumi yang subur dan mempunyai beraneka ragam sumber alam yang dapat diolah menjadi bahan makanan. Sesuai dengan hasil penelitian dari tanggal 17 - 21 Juli 2017 siswa kelas IPA-2 ke sekolah SMAN I Bukit di Kebupaten Bener Meriah. Subjek dalam penelitian ini adalah siswa kelas X SMA N 1 Bukit yang berjumlah 25 siswa. Rancangan penelitian yang digunakanadalah Penelitian Tindakan Kelas (PTK) yang terdiri dari perencanaan, tindakan, pengamatan danrefleksi.Teknik pengumpulan data yang digunakan dalam penelitian ini dengan cara observasi, test dan angket. Data yang diperoleh dianalisismenggunakanpersentase mengenai minat kewirausahaan, dan responsiswa dengan pendekatan ChemoEntrepreneurship (CEP) pada materi perubahan kimia. Minat kewirausahaan siklus I 20\% pada siklus ke II menjadi $47 \%$ dan ternyata respon siswa yang menyatakan positif sekitar $83,2 \%$ dan menyatakan negative hanya $16,8 \%$
\end{abstract}

Kata Kunci : Lulusan, Pembelajaran Kimia, Chemo-Entrepreneurship,Perubahan Materi, dan penelitian PTK

\section{Pendahuluan}

Rendahnya mutu lulusan berakibat pada rendahnya kemampuan kompetitif dan komperatif lulusan. Lembaga Pendidikan Sekolah Menengah Atas (SMA/SMK) memiliki tujuan mempersiapkan siswa untuk melanjutkan ke jenjang pendidikan yang lebih tinggi,. Namun pada kenyataannya banyak siswa SMA/SMK yang tidak dapat melanjutkan ke jenjang pendidikan yang lebih tinggi sehingga berpotensi untuk menjadi pengangguran [1].

Bila kita perhatikan angka partisipasi kasar untuk jenjang perguruan tinggi maka hanya $23 \%$ total siswa yang berkesempatan melanjutkan pendidikan ke perguruan tinggi. Artinya $77 \%$ tidak melanjutkan ke perguruan tinggi. Dari $77 \%$ tersebut sebagian di antaranya memasuki dunia kerja, sebagian lagi terombang-ambing menjadi pengangguran, sebagian mencoba berwirausaha dan sebagian memasuki kehidupan berumah tangga. Biasanya yang berminat melanjutkan ke pendidikan tinggi adalah tamatan SMU. Sedangkan yang siap memasuki lapangan kerja adalah tamatan SMK. Dengan angka 23\% yang melanjutkan ke perguruan tinggi maka persentase tamatan SMU yang tidak melanjutkan pendidikan ke perguruan tinggi cukup besar jumlahnya. [1]. Hinduan [2] menyatakan untuk berhasil dalam kehidupan nyata setelah lulus pendidikan menengah maupun perguruan tinggi tidak hanya berbekal selembar ijazah, tetapi harus memiliki kemampuan untuk memasarkan pengetahuan, memiliki jiwa entrepreneurship (kewirausahaan), jujur, ulet, kreatif, dan kemampuan memahami dan merespon pasar.

Menurut Purnomo [3], minat kewirausahaan para siswa dapat ditingkatkan melalui pendidikan, dalam hal konteks pengembangan sumber daya mamusia, pendidikan sebagai usaha sadar diarahkan untuk mengembangkan potensi siswa agar dapat diwujudkan dalam bentuk kemampuan, ketrampilan, sikap,dan kepribadian sesuai dengan tujuan 
pendidikan nasional. Dalam proses pembelajaran perlu adanya suatu pendekatan dalam pembelajaran sesuai dengan penjelasan Supartono [4] menjelaskan Pendekatan pembelajaran berorientasi Chemo-Entrepreneurship merupakan suatu inovasi pendekatan pembelajaran yang menekankan pada kegiatan proses belajar mengajar yang dikaitkan objek nyata (kontekstual) sehingga selain mendidik, dengan pendekatan ini siswa dapat mengolah proses pengolahan suatu bahan menjadi produk yang bermanfaat dan bernilai ekonomi. Sesuai dengan hasil sosialisasi ke sekolah SMA/SMK di Kebupaten Bener Meriah pada tanggal 28-29 Maret 2016 tentang Entrepreneurship adalah salah satu kunci kesuksesan, antusias dari siswa-siswa tersebut akan berwirausaha sangat tinggi dengan melihat sumber daya alam yang terdapat di bumi Bener Meriah dengan berbagai tanaman palawija cukup berlimpah. Perludipahamibahwasumberdayamanusia merupakandasarbagisuatubangsa.Modal dan sumber daya alam adalah merupakan faktor-faktor produksi yang pasif, manusia merupakan faktor produksi yang aktif. Manusia dikatakan sebagai faktor produksi yang aktif, karena memiliki kemampuan mengumpulkan modal, mengeksploitasi sumbersumber daya alam yang berlimpah. Berdasarkan latar belakang diatas maka setiap proses pengajaran yangdilakukan oleh gurumempunyai tujuan masing-masing untuk terlaksananya proses belajar mengajar dengan baik. Dalam hal ini untuk mendukung upaya mewujudkan tujuan Pendidikan Nasional, maka perlu diakukan penelitian tentang "Peningkatan Minat Kewirausahaan Siswa SMA N 1 Bukit Bener Meriah Pada Pembelajaran Kimia Dengan Pendekatan Chemo-Entrepreneurship". Dan tujuan penelitian untuk mengetahui minat siswa dalam berwirausaha, dan respon siswa terhadap pelajaran kimia pada perubahan materi.

Kimia merupakan ilmu yang pada awalnya diperoleh dan dikembangkan berdasarkan percobaan (induktif), tetapu pada perkembangan selanjutnya kimia juga diperoleh dan dikembangkan berdasarkan teori (deduktif) . Kimia adalah ilmu yang mencari jawaban atas pertanyaan apa, mengapa, dan bagaimana gejala - gejala alam yang berkaitan dengan komposisi, srtuktur,dan sifat, perubahan,dinamika, serta energitika zat. Oleh karena itu, maka pelajaran kimia di SMA/MA mempelajari segala sesuatu tentang zat yang meliputi komposisi, struktur dan sifat, perubahan, dinamika,serta energetika zat yang melibatkan ketrampilan dan penalaran. Ada dua hal yang berkaitan dengan kimia yang tidak dapat dipisahkan yaitu kimia sebagai produk (pengetahuan kimia yang berupa fakta, konsep, prinsip, hukum, dan teori) temuan ilmuan dan kimia sebagai sebagai proses (kerja ilmiah). Maka pembalajaran kimia dan penilaian hasil belajar kimia harus memperhatikan karakteristik ilmu kimia sebagai proses dan produk.

Secara lebih khusus, mata pelajaran kimia diajarkan untuk tujuan membekali siswa pengetahuan, pemahaman, akan lingkungan kehidupan sehari-hari. Tujuan mata pelajaran kimia dicapai oleh siswa melalui berbagai pendekatan dan metode pembelajaran serta media yang digunakan, pada saat pembelajaran berlangsung. Pembelajaran kimia menekankan pada pemberian pengalaman belajar secara langsung melaluipenggunaan dan pengembangan ketrampilan proses dan sikap ilmiah.

Peristiwa atau reaksi kimia sangat erat hubungannya dengan kehidupan kita sehari-hari (Life is chemistry ). Semua zat penyusun tubuh dan semua makanan yang masuk ke dalam tubuh kita merupakan zat-zat kimia, yang harus mengalami berbagai reaksi lebih dahulu sebelum berfungsi sebagai sumber tenaga. Setiap hari senantiasa bergaul dengan benda-benda yang dihasilkan oleh suatu industry kimia,seperti sabun, pasta gigi, pakaian, minuman, makanan buah yang lezat. Kemudian berkat kemajuan teknologi yang semakin pesat manusia telah mampu membuat serat-serat sintetis seperti nilon, pengolahan minyak menjadi bahan plastic, memproduksi obat-obatan , kosmetik,pupuk, film fotografi dan pita kaset, serta peralatan cangkih bagi teknologi mutakhir seperti liquid crystal, superkonduktor, dan bahan keramik [5]. Menurut Ery susanti [6] entrepreneur diartikan sebagai orang yang pandai memanfaatkan peluang usaha lalu menterjemahkannya menjadi usaha yang memiliki nilai tambah. Entrepreneur adalah seorang motivator yang menggabungkan teknologi yang berbeda dan konsep-konsep bisnis untuk menghasilkan produk atau jasa baru yang mampu mengenali setiap kesempatan yang menguntungkan, menyusun strategi dan yang berhasil menerapkan ide-idenya.Erpreneurship adalah segala hal yang berkaitan dengan sikap, tindakan dan proses yang dilakukan oleh para erpreneur dalam merintis, menjalankan dan mengembangkan usaha mereka.

Di dunia pendidikan terdapat pendekatan pembelajaran yang sangat beragam. Setiap pendekatan pembelajaran memiliki kelebihan dan kekurangan. Penggunaan metode dan pendekatan dalam pembelajaran yang tepat akan memberikan peningkatan kemampuan dan minat siswa dalam belajar kimia. Pembelajaran yang menarik dengan mengaitkan konsep kimia yang dipelajarai dengan mengaplikasikannya dalam kehidupan sehari-hari, sehingga pembelajaran kimia tersebut merupakan pembelajaran yang menarik serta memupuk daya kreatifitas dan inovasi siswa.Pembelajaran tersebut sebagai pendekatan pembelajaran Chemo-Entrepreneurship (CEP) yang dijelaskan oleh 
Sa'adah. N dan Supartono [7] yaitu Pembelajaran CEP senantiasa memberikan kesempatan kepada siswa untuk berlatih menggunakan ketrampilan-ketrampilan proses tersebut, siswa diberi peluang untuk melaksanakan kerja ilmiah dan diekplorasikan potensinya secara optimal, agar peluang siswa benar-benar terlibat aktif secara fisik dan mental dalam belajar kimia.

Melalui pendekatan CEP siswa diajarkan untuk mengkaitkan langsung pada objek nyata atau fenomena di sekitar kehidupan manusia, sehingga selain mendidik dengan pendekatan pembelajaran CEP ini memungkinkan siswa dapat mempelajari proses pengolahan suatu bahan menjadi produk yang bermanfaat, bernilai ekonomi, dan menimbulkan minat siswa untuk berwirausaha. Dengan pendekatan pembelajaran ini menjadikan pelajaran kimia itu lebih menarik, menyenangkan dan lebih bermakna [8]. Dalam penelitian Sri.K, Subiyanto. H.P, dan Sigit. P [9] menjelaskan pembelajaran dengan pendekatan CEP juga meningkatkan hasil belajar mahasiswa pada mata kuliah kimia fisika 5.Mahasiswa tertarik dan pembelajarn tidak menoton,ada sikap entrepreneurship di dalamnya, dan pembelajaran tersebut harus menghasilkan produk yang mudah dipasarkan.

\section{Metodelogi Penelitian}

Populasi Semua Siswa kelas X SMA N 1 Bukit yang berjumlah 136 siswa yang tersebar dalam 6 kelas. Subjekpenelitianiniadalahsiswa kelas X-IPA.2yangberjumlah 25siswayangterdiri dari7putradan18putri.Pengambilan sampel secara Purposive Sample. Berdasarkan dari Suharsimi Arikunto [10] menjelaskan sebagai berikut: Subjek yang diambil sebagai sampel benar-benar merupakan subjek yang paling banyak mengandung ciri-ciri yang terdapat pada populasi.Pendekatan penelitian yang digunakan dalam penelitian ini adalah pendekatan kualitatif. Pendekatan ini berkenaan dengan perbaikan atau peningkatan proses dan hasil pembelajaran pada suatu kelas.

Penelitian ini menggunakan desain PenelitianTindakan Kelas (Classroom Action Research) yang terdiri dari dua siklus.. Penelitian Tindakan Kelas menurut Wina Sanjaya [11] yaitu, Setiap siklus mencakup empat tahapan kegiatan yaitu (1) Perencanaan (planning) (2) Pelaksanaan tindakan (acting) (3) Pengamatan (observing) dan (4) Refleksi (reflecting). Dengan teknik analisis deskriptif kualitatif. Penelitian Tindakan Kelas dipilih sebagai sebuah upaya meningkatkan minat belaja rsiswa dan pemahaman materipeserta didik dalam pembelajaran dikelas dengan pendekatan Chemo-Entrepreneurship (CEP).

Sebagai indikator meningkatkatnya minat belajar siswa dan pemahaman materi kimia pada pembelajaran adalah siswa kurang kelihatan minat atau respon dalam pembelajaran dan tidak ada saling berkomunikasi antar siswa, baik secara lisan maupun tertulis.Data yang didapatkan adalah data kualitatif yang terdiri dari hasil observasi terhadap pelaksana proses pembelajaran dan hasil wawancara terhadap subjek penelitian yaitu guru dan siswa, pada siklus pertama, siklus kedua [12].

\section{Hasil Penelitian dan Pembahasan}

\section{Siklus I}

Berdasarkan data angket sebelum pembelajaran dengan pendekatan CEP, dapat dilihat pada gambar 1. Bahwa minat siswa terhadap pelajaran kimia dalam kategori minat "sadang-sedang saja" dimana antara setuju dan kurang setuju sama nilainya yaitu 32\% dengan 8 orang menyatakan setuju dan $32 \%$ dengan 8 orang juga yang menyatakan kurang setuju dari 25 orang siswa. Pada siklus I ini minat siswa sama banyak antara berminat dan kurang berminat 


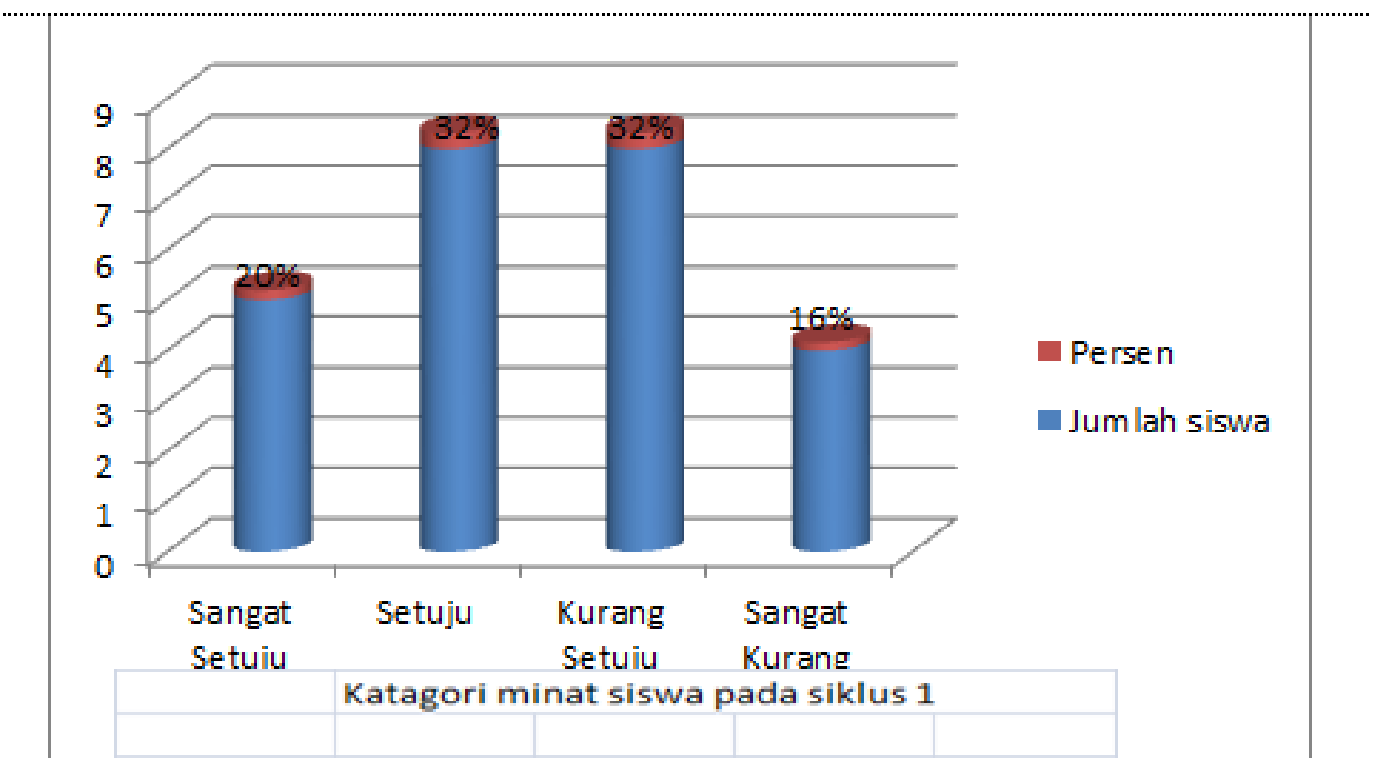

Gambar 1. Kategori minat pada siklus I

Berdasarkan hasil observasi kegiatan peneliti pada siklus 1 yang disajikan pada gambar 1, dapat dismpulkan bahwa kegiatan peneliti belum berhasil dengan baik. Hal ini ditunjukan pada minat siswa antara setuju dan kurang setuju sama banyak. Kurang minat belajar siswa disebabkan banyak faktor, yaitu palaran kimia baru diterima di SMA, pelajaran kimia banyak yang membingungkan, peelajaran kimia susah untuk dimengerti dan pelajaran kimia abstrak, sehingga siswa banyak yang kurang serius ketika proses pembelaran berlangsung.

\section{Refleksi}

Setelah menyajikan data hasil observasi, maka tahap terakhir yang perlu dipaparkan pada siklus ini adalah refleksi tindakan. Pada pelaksanaan tindakan siklus I ini dapat dikemukakan bahwa secara umum siswa berminat mengikuti pembelajaran dengan menggunakan pendekatan Chemo-Entrepreneurship (CEP), namun ada sebagian siswa yang tidak setuju disebabkan karena siswa masih kurang berminat belajar kimia dalam proses pembelajaran

Namun pada kegiatan siklus I yang dikemukakan kelemahan dan kelebihan melalui diskusi dengan siswa ternyata hasil yang ditemukan sebagai berikut pada:

\section{Kelemahan:}

Sisiwa belum berminat untuk mempelajari kimia sehingga tidak terlihat adanya respon siswa terhadap materi pembelajaran kimia yang ditandai dengan ketidak seriusan selama proses belajar mengajar.

Respon siswa belum sepenuhnya berfokus pada materi pembelajaran, hal ini dibuktikan siswa masih banyak melakukan kegiatan-kegiatan yang tidak mendukung kelancaran pembelajar

\section{Kelebihan:}

Pada siklus ini peneliti menggunakan pendekatan CEP yang disesuaikan dengan materi pelajaran kimia dengan tujuan untuk membantu pemahaman siswa terhadap materi yang dipelajari

Peneliti mempunyai perencanaan dalam melaksanakan pembelajaran sehingga proses pembelajaran teratur sesuai dengan langkah-langkah pada penelitian PTK

\section{Siklus II}

Observasi dilakukan oleh teman sejawat masih mengarah pada dua subjek yaitu guru dan siswa. Adapun hasil pengamatan pada siklus I I. Setelah dilakukan pemantapan dan pengarahan materi perubahan materi dengan mempelajari sifat kimia dan sifat fisika dari materi secara demontrasi dengan menggunakan LKK secara berkelompok maka dapat aktivitas siswa untuk memperhatikan dan melakukan demontrasi sangat antusias dan 
dapat meningkatkan minat belajar siswa, hal ini dapat dilihat pada pertemuan ke dua pada siklus kedua dapat dilihat pada gambar 2 .

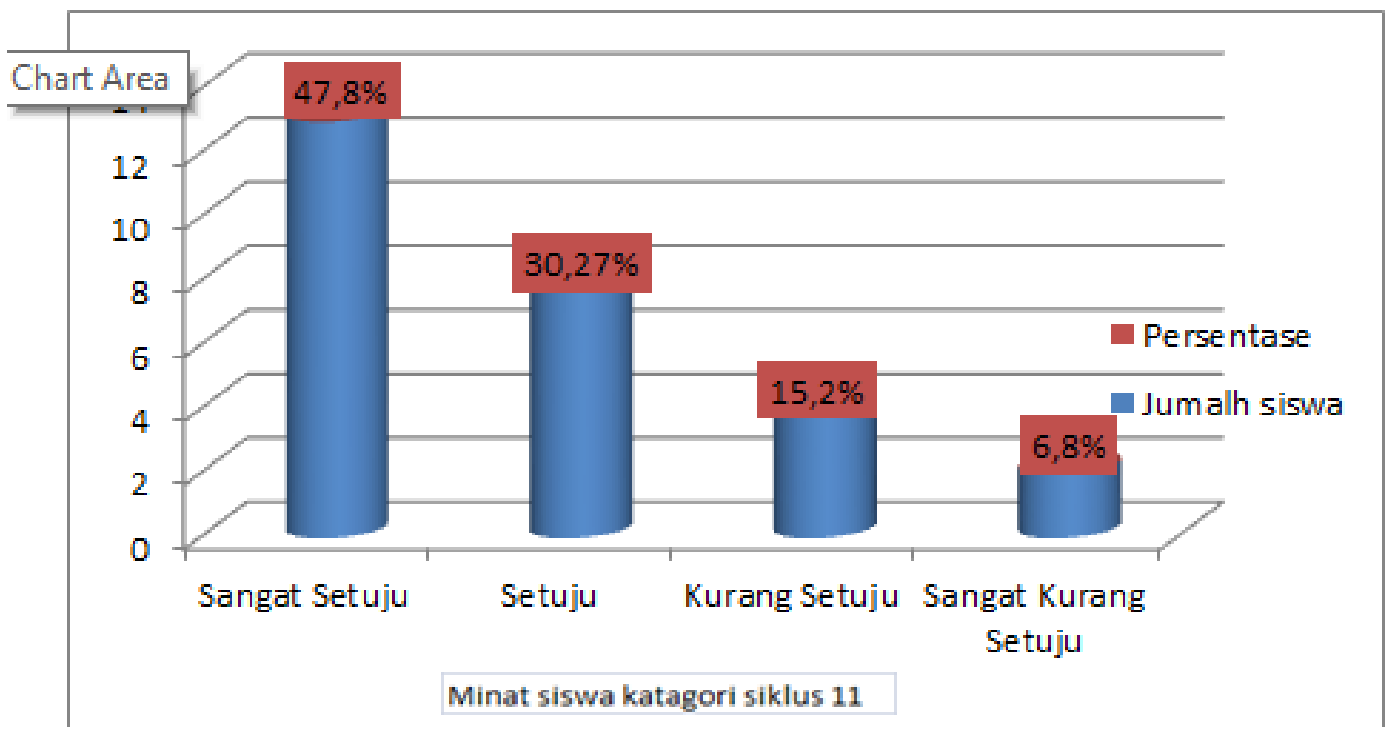

Gambar 2. Kategori minat pada siklus II

Dari gambar 2, data Minat siswa terhadap kewirausahaan setelah dilaksanakannya siklus II mengalami peningkatan, meskipun hanya sedikit. Hal ini dapat dilihat dari data nilai evaluasi berikut ini. Pada siklus pertama sangat setuju 5 siswa dengan persentase $20 \%$, meningkat menjadi 13 dengan persentase yaitu 47\%, untuk yang setuju dari 8 siswa dengan persentase 32\% sama dengan siklus yang ke 2 yaitu 8 siswa juga, kurang setuju 8 siswa dengan persentase $32 \%$ menurun menjadi 4 siswa dengan persentasenya $15,2 \%$, dan untuk yang sangat kurang setuju tinggal 4 siswa dengan pesentasenya $16 \%$, menjadi 2 siswa lagi dengan pesentasenya $6,8 \%$ sudah menurun. Setelah menelaah, mempelajari dan mendiskusikan dengan siswa data observasi, dapat disimpulkan pada siklus II ini sebagai berikut, Kegiatan belajar siswa belajar siswa semakin aktif dan dapat dikatakan berhasil. Peneliti berhasil membangkitkan minat belajar siswa dengan mengaplkasikan pendekatan chemo-Entrepreneurship (CEP) dalam pelajaran kimia.

Kemudian Data tanggapan guru mengenai bahan ajar CEP, diperoleh dengan memberikan kuesioner kepada guru untuk kemudian diisi sesuai dengan pendapat masing-masing. Guru kimia yang mengajar di SMAN 1 Bukit ada 3 orang yang sistem mengajar yaitu untuk 1 orang mengajar dari kelas X IPA dan X IPS, 1 orang yang lagi mengajar hanya kelas XI IPA dan 1 orang guru lagi di kelas XII IPA. Hasil tanggapan guru diperoleh bahwa ratarata $95 \%$ guru memberikan tanggapan yang positif terhadap bahan ajar CEP dan 4,4\% yang menyatakan negative dengan alas an sebagai berikut" Pada bahan ajar masih banyak kurang contoh-contoh yang ada dilingkungan sehingga dapat diciptakan suatu peluang usaha bagi siswa - siswa yang tidak melanjutkan pendidikan" kemudian data tanggapan siswa tanggapan siswa diperoleh rata-rata $83 \%$ siswa memberikan tanggapan positif dan dan 16,8\% yang menyatakan negative dengan jumlah si sebanyak 25 siswa.

Siklus II, pelaksanaan tindakanpada siklus II dengan pendekatan Chemo-Entrepreneurship (CEP) pada proses pembelajaran. Peneliti harus berusaha semaksimal mungkin dalam pengelolaan kelas, memotivasi dan membimbing siswa sehingga pada siklus ini nampak perubahan yang mengarah pada kesempurnaan pembelajaran dan sudah menunjukan kriteria baik, halini terlihat jelas pada aktifitas belajar siswa yang dapat bertanya dan menjawab pertanyaan, menunjukan partisipasi dalam kelompok dalam melakukan demontrasi sesuai dengan petunjuk pada LKK, serta dapat menyimpulkan materi bersama guru. Berdasarkan hal tersebut diperoleh data hasil observasi yang disimpulkan bahwa proses pembelajaran dengan menggunakan pendekatan Chemo-Entrepreneurship (CEP) dapat meningkatkan minat belajar siswa. 


\section{Kesimpulan}

a. Minat siswa terhadap kewirausahaan setelah dilaksanakannya siklus II mengalami peningkatan, meskipun hanya sedikit. Hal ini dapat dilihat dari data nilai evaluasi berikut ini. Pada siklus pertama sangat setuju 5 siswa dengan persentase $20 \%$, meningkat menjadi 13 dengan persentase yaitu $47 \%$, untuk yang setuju dari 8 siswa dengan persentase 32\% sama dengan siklus yang ke 2 yaitu 8 siswa juga, kurang setuju 8 siswa dengan persentase $32 \%$ menurun menjadi 4 siswa dengan persentasenya $15,2 \%$, dan untuk yang sangat kurang setuju tinggal 4 siswa dengan pesentasenya $16 \%$, menjadi 2 siswa lagi dengan pesentasenya $6,8 \%$ sudah menurun.

b. Tanggapan guru diperoleh bahwa rata-rata $95 \%$ guru memberikan tanggapan yang positif terhadap bahan ajar CEP dan 4,4 \% negative. Berdasarkan tanggapan siswa diperoleh rata-rata $83 \%$ siswa memberikan tanggapan positif dan dan 16,8\% yang menyatakan negative dengan jumlah si sebanyak 25 siswa.

Berdasarkan pengalaman selama melaksanakan penelitian tindakan kelas maka peneliti mengajukan saran-saran: Pembelajaran kimia yang digunakan peneliti dengan menggunakan bahan ajar CEP dan mengaplikasikan semua contoh-contoh materi kimia ke dalam kehidupan sehari-hari atau kedunia nyata maka akan meningkatkan, motivasi, minat dan hasil belajar siswa tentang kimia, demi tercapainya tujuan pembelajaran. Dan mendorong siswa untuk menjadi Entrepreneurship dengan mengolah hasil pertanian yang mereka miliki

\section{Referensi}

[1] Rahmad Daulay, 2015.Pasca Ujian Nasional.http://hminews.com/opini/pasca-ujian- nasional-2015/)

[2] Hinduan,(200\3),Meningkatkan Kualitas SDM Melalui Pendidikan IPA. Makalah Utama disajikan dalam seminar Nasional tanggal 1-4 Agustus 2004 di UPI Bandung.

[3] Purnomo, H.B. 2005. Membangun semanagt Kewirausahaan. Yogyakarta: Laksbang Pressindo

[4] Supartono, 2006. Upaya Peningkatan Hasil Belajar dan Kreativitas Siswa SMA Melalui Pembelajaran Kimia Dengan Pendekatan ChemoEntrepreneurship. Makalah Yang disampaikan pada Seminar Nasional Kimia dan Pendidikan Kimia Jurusan Kimia FMIPA UNNES tanggal 11 November 2006, Semarang: Jurusan Kimia FMIPA UNNES

[5] Irfan Ansyory. Dan Hiskia.A, 2003. Acuan Pelajaran Kimia SMU.Untuk Kelas 1. Jakarta: Erlangga.

[6] Ery susanti. 2007. Peningkatan Kreatifitas dan Hasil Belajar Kimia Melalui Pendekatan CEP Dengan Bantuan Game Simulation di SMA N 9 Semarang (Skripsi). Semarang: Jurusan Kimia FMIPA UNNES.

[7] Supartono, 2013. Penggunaan Pendekatan Chemoentrepreneurship pada Materi Larutan Penyangga Untuk Meningkatkan Life Skill Siswa. http://Journal .unnes.ac.id/sju/index.phd/chemined.

[8] Sri. K, Subiyanto. HS, dan Sigit, 2010. Upaya Peningkatan Hasil Belajar Kimia Fisika 5 Dengan Pendekatan Chemo-Entrepreneurship Melalui Kegiatan Lesson Study. Jurnal Inovasi Pendidikan Kimia, Vol. 4. No. 1. Hlm 532-543.

[9] Supartono, Nanik. W, dan Anita. HS, 2009. Kajian Prestasi Belajar siswa SMA Dengan Metode Student Teams Achievement Divisions Malalui Pendekatan Chemo-Entrepreneurship. Jurnal Inovasi Pendidikan Kimia, Vol.3 No.1. hlm 337-344.

[10] Suharsimi Arikunto, 2010. Prosedur Penelitian Suatu Pendekatan Praktik. Jakarta: PT. Asdi Mahasatya

[11] Wina Sanjaya ,2013. Penelitian Tindakan Kelas. Jakarta: Kencana Prenadamedia Group 